\title{
Person Postal Address
}

National Cancer Institute

\section{Source}

National Cancer Institute. Person Postal Address. NCI Thesaurus. Code C93990.

A contact point used to send physical forms of communication to the person. 